\title{
Treatment Principles for Coccygodynia
}

\author{
Koksigodiniyada Tedavi Prensipleri
}

\author{
Sedat DALBAYRAK ${ }^{1}$, Onur YAMAN² ${ }^{2}$ Tevfik YILMAZ ${ }^{3}$, Mesut YILMAZ ${ }^{4}$ \\ ${ }^{1}$ Neurospinal Academy, Istanbul, Turkey \\ ${ }^{2}$ Tepecik Education and Training Hospital, Clinic of Neurosurgery, Izmir, Turkey \\ ${ }^{3}$ Dicle University, School of Medicine, Department of Neurosurgery, Diyarbakır, Turkey \\ ${ }^{4}$ Neurospinal Academy, Istanbul, Turkey
}

Corresponding Author: OnurYAMAN / E-mail: dronuryaman@yahoo.com

\begin{abstract}
AIM: An evaluation of treatment methods and outcomes for coccygodynia cases that do not respond to conservative treatment.

MATERIAL and METHODS: Local anesthetic and steroid injections were applied in 32 coccygodynia cases that did not respond to conservative treatment (average of 15 months). Coccyx excision was performed as surgical treatment in 25 cases that had pain relief after the injections but later re-presented with complaints. The patients' pain levels were assessed with VAS. Postacchini classification was used for patient classification based on plain radiography.

RESULTS: 20 (62\%) of the cases (the total including injection and surgery groups) had a trauma history. Majority of the cases treated with local steroid injection included patients with Type I, while the 25 cases that received surgical treatment predominantly included Type II patients. One case had post-operative skin infection, which was treated with antibiotics. It was observed by comparing pre-operative and post-operative pain scores that both methods provided significant pain relief in all patients.
\end{abstract}

CONCLUSION: While local steroid injection is an effective method of treatment for Type I patients, the coccyx removal is an effective method for controlling the pain in patients with trauma history and in Type II, III and IV patients.

KEYWORDS: Coccygodynia, Treatment, Steroid injection, Coccyx excision

öz

AMAÇ: Konservatif tedaviye yanıt vermeyen koksigodiniya olgularında tedavi yöntemleri ve sonuçlarının değerlendirilmesi.

YÖNTEM ve GEREÇLER: Konservatif tedaviye (ortalama süre: 15 ay) yanıt vermeyen 32 koksigodiniya olgusuna lokal anestezik ve steroid enjeksiyonu uygulandı. Enjeksiyon sonrası ağrıları geçen ancak bir süre sonra yakınmaları tekrar ortaya çıkan 25 olguya cerrahi olarak koksiks eksizyonu uygulandı. Hastaların ağrı düzeyleri VAS ile değerlendirildi. Hastalar direkt grafilerde Postachini sınıflamasına göre sınıflandıııldı.

BULGULAR: Olguların 20'sinde (\%62) (Enjeksiyon ve cerrahi grubu toplamı) travma hikayesi mevcuttu. Lokal steroid enjeksiyonu ile tedavi hastaların büyük kısmı Tip I iken cerrahi olarak tedavi edilen 25 olguda daha çok Tip II hastalar mevcuttu. Cerrahi sonrası cilt enfeksiyonu gelişen bir olguya uygulanan antibiyotik kullanımı ile tedavi sağlandı. Tedavi öncesi ve sonrası ağrı şiddeti karşılaştırıldığında tüm hastalarda, her iki yöntemle de anlamlı olarak ağrının azaldığı gözlendi.

SONUÇ: Koksigodiniya tedavisinde Tip I hastalarda lokal steroid enjeksiyonu etkili bir yöntemken; travma hikayesi olan ve tip II, III, IV hastalarda koksiksin çıkarılması ağrıyı kontrol etmekte etkin bir yöntemdir.

ANAHTAR SÖZCÜKLER: Koksigodiniya, Tedavi, Steroid enjeksiyonu, Koksiks eksizyonu

\section{INTRODUCTION}

Coccygodynia is a term used to describe the pain in and around the coccyx. It is usually observed in women and more likely in the forties (3). The incidence rate of coccygodynia is 3 times higher in obese patients than in those with normal weight. Especially the post-traumatic instability causes hypermobility in the coccyx. And the hypermobility causes chronic inflammatory changes (3). The coccygeal pain is usually increased by sitting and attempting to move. Nonsurgical therapy is the gold standard in coccygodynia treatment. Principal methods of pain reduction include analgesic use, limitation of sitting, use of ring shaped pillow and physiotherapy. Effective pain relief can be achieved with injection of steroid and long acting local anesthetic combination (1). Surgical removal of the coccyx is required in patients that do not respond to conservative treatment and attempts of pain reduction with local steroid injection.

This study aims at evaluating the treatment methods and outcomes of cases treated for coccygodynia.

\section{MATERIAL and METHODS}

The study includes 32 cases of coccygodynia that did not respond to conservative treatment. Detailed clinical history was taken for all patients. Detailed questions were asked to discover any past trauma and childbirth incidents. Other factors in the anal region such as fissure and haemorrhoid 
were excluded by rectal examination supplemental to the neurological examination. Two-directional lumbosacral vertebral and coccyx x-rays were taken. MRI was used for evaluating the lumbosacral region in order the rule out the underlying pathology. The patients were grouped according to the Postacchini and Massobrio classification (7). This method measures the angle between the coccygeal region and proximal sacrococcygeal region distal to the painful joint. According to this measurement patients with no angulation were classified as Type 1, those with sharper forward curvature and angulation less than 90 degrees as Type 2, those with angulation of 90 degrees as Type 3 and those subluxated at the sacrococcygeal or intercoccygeal joint and angulation exceeding 90 degrees as Type 4 (7) (Table I). Pain levels and life quality index were assessed by VAS.

\section{Surgical Procedure}

The patients were placed on the operating table in the prone position under spinal anaesthesia. Hips and knees were fixed in semiflexion by moving the legs away as far as possible. An 8 to $10 \mathrm{~cm}$ longitudinal linear skin incision was made to dissect the skin and the subcutaneous tissue. Once the coccyx was exposed, subperiosteal dissection was made to reach the lateral part of the coccyx, and it was disarticulated from the sacrococcygeal joint by using a Kerrison rongeur. Rectal injury was avoided by going from distal to the anterior part of the coccyx. The coccyx was detached from the soft tissue by blunt dissection. Complete coccyx removal was performed distally by dissecting the anococcygeal ligament. The distal tip of the sacrum was filed. Layers were closed appropriately with placement of a Hemovac drain. The patients received 48-hour antibiotherapy after the surgery (cefazolin 2gr/day).

\section{RESULTS}

Out of 32 patients, 24 were female $(75 \%)$ and 8 (25\%) were male. The mean age was 34 (27-56). Pain relief could be achieved in 7 patients with the use of steroid and long acting local anesthetic injections. Average pre-injection VAS score was 7.2, whereas the post-injection VAS score was 1.2. The mean age in this patient group was 34 (ages varying between 27 and 45) and one but all patients were women. 4 patients had pregnancy and childbirth history, while 2 patients had trauma history. According to Postacchini classification, one patient was classified as Type II (15\%), while the others were classified as Type I (7 patients) (85\%) (Table II).

Out of 25 patients in the group that was non-responsive to steroid and local anesthetic injections, 18 were female (72\%) and 7 were male (28\%). The mean age was recorded as 38.5 (ages varying between 29 and 56). 18 patients (72\%) had trauma history. The average pre-operative VAS score was 8.32, while the post-operative VAS score was 1.40 . According to Postacchini classification, 5 patients were Type I (20\%), 16 were Type II (64\%), 3 were Type III (12\%) and 1 was Type 4 (4\%) (Table II).

\section{DISCUSSION}

The etiology of coccygodynia has not been clearly explained due to the complex anatomy of the sacral region. Coccygodynia usually occurs after trauma. It occurs after falling in the sitting position or on narrow objects that will cause direct impact to the coccyx. Childbirth, anal intercourse or neoplasm involving primary or secondary coccyx may lead to coccygodynia. Coccygodynia may also occur due to infection or inflammation that cause irritation of the pelvic structures, or involvement of the sacrum, sacral roots or parts of lumbosacral plexus as first symptoms of disc herniation. Patients with no known pathology are classified as idiopathic.

Especially the post-traumatic instability causes hypermobility in the coccyx. And the hypermobility causes chronic inflammatory changes (3). Synovial arthritis develops at the sacrococcygeal joint. The coccygeal pain usually occurs during sitting and the attempt to move, while it is relieved by rest. One must be very careful about lower back and coccygeal pain that is not relieved but increased by a night full of rest. Malignity should be considered when there is night pain (8). Pathology of the anus such as haemorrhoid and fissure must be excluded by performing rectal touch during examination, and the prostate must be examined for malignity (8).

The coccyx demonstrates a coccygeal pivot of 5 to 25 degrees with sitting and returning to the normal position with standing. Instead of stable $x$-rays, dynamic plain $x$-rays taken at sitting or standing position will have $70 \%$ contribution to diagnosing the coccygodynia (3). Postacchini et al. used lateral plain $x$-rays of the sacrococcygeal region for the classification of coccygodynia (7) (Table I) (Figures 1A-D,2A,B,-3A-F). This method measures the angle between the coccygeal region and proximal sacrococcygeal region distal to the painful joint. According to this measurement patients with no angulation were classified as Type 1, those with sharper forward curvature and angulation less than 90 degrees as Type 2, those with angulation of 90 degrees as Type 3 and those subluxated at the sacrococcygeal or intercoccygeal joint and angulation exceeding 90 degrees as Type 4 (Figures $1 A-D, 2 A, B,-3 A-F$ ).

Table I: Postacchini Classification and Types Based on Angulation at the Sacrococcygeal Joint

\begin{tabular}{|l|l|}
\hline $\begin{array}{c}\text { Types } \\
\text { Type I }\end{array}$ & \multicolumn{1}{|c}{ Evaluation } \\
\hline Type II & Patients with forward curvature and absence of angulation \\
\hline Type III & Patients with sharper forward curvature and angulation less than 90 degrees \\
\hline Type IV & Subluxation or angulation exceeding 90 degrees at the sacrococcygeal joint \\
\hline
\end{tabular}


Severity of the pain increases from Type I to Type IV (7). In our series, severity of the pain usually increased with higher angulation. Magnetic Resonance (MR) and technetium Tc$99 \mathrm{~m}$ bone scan help to localize the inflammation that occurs due to coccygeal hypermobility (3). They are also required for excluding any coccygeal pathology that causes pain (2).

Non-surgical therapy is the gold standard in coccygodynia treatment. Principal methods of pain reduction include analgesic use, limitation of sitting, use of ring shaped pillow and physiotherapy (3). Levator ani massage and stretch are reported as effective methods of pain relief (5). Rectal massage is reported to achieve pain relief by stretching the muscles and connective tissue attached to the coccyx and relieving the spasm (6).

Pain relief can be achieved with conservative treatment in one forth of the patient population. Success rate is $43 \%$ in a coccyx with normal movement capability, while it declines to $16 \%$ in an immobile coccyx. Resting, sitting on ring-shaped pillows and NSAI drugs must be tried for 2 months at the initial stage of treatment. Local steroid injection must be tried for persistent pain despite conservative treatment. Steroid (40 mg methylprednisolone) and long-acting local anesthetic (10 $\mathrm{ml} 0.25 \%$ bupivacaine) combination is reported to help pain relief. Wray et al. reported a success rate of $85 \%$ for injection and manipulation in 120 patients (11).

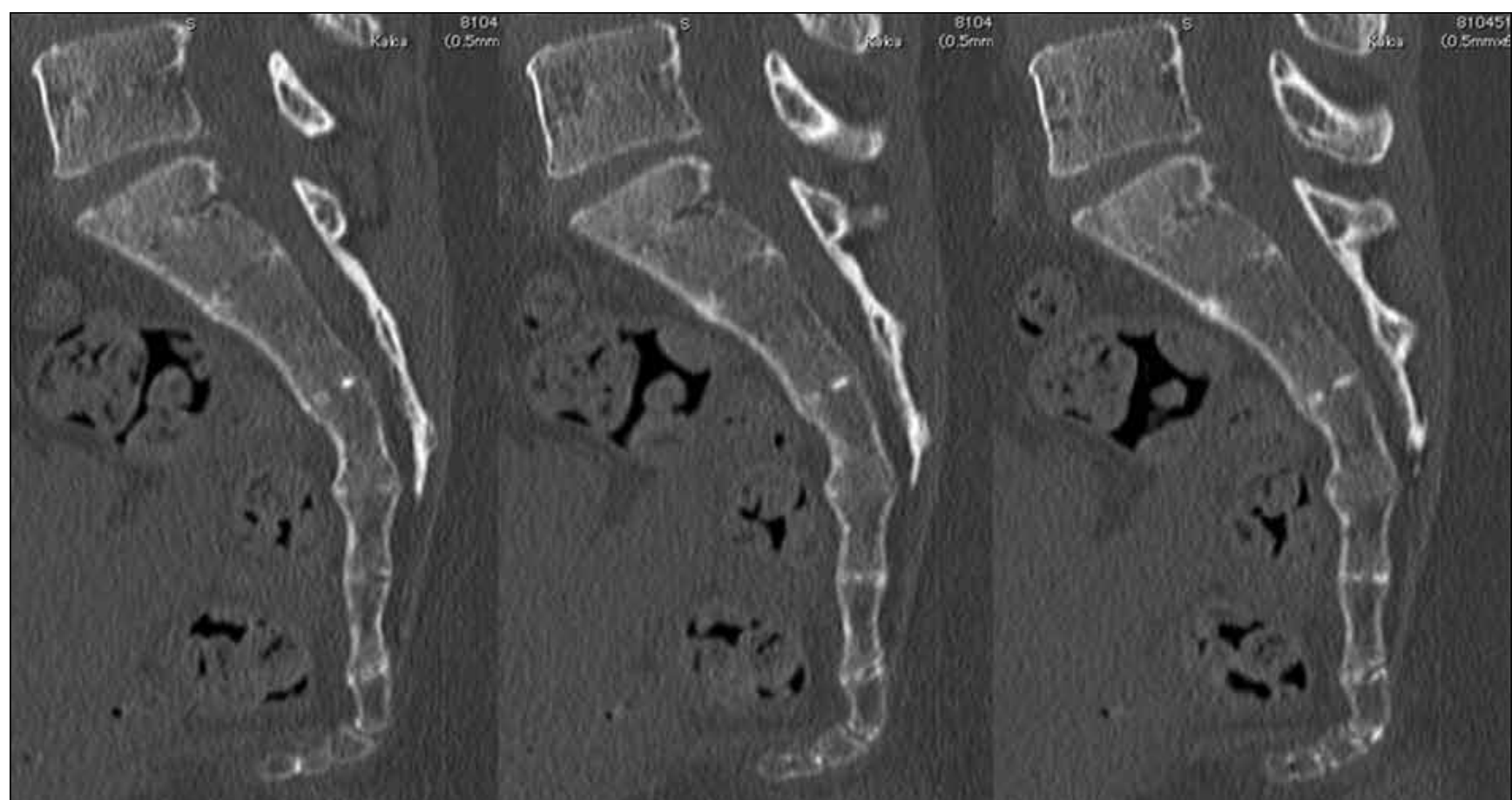

(A)

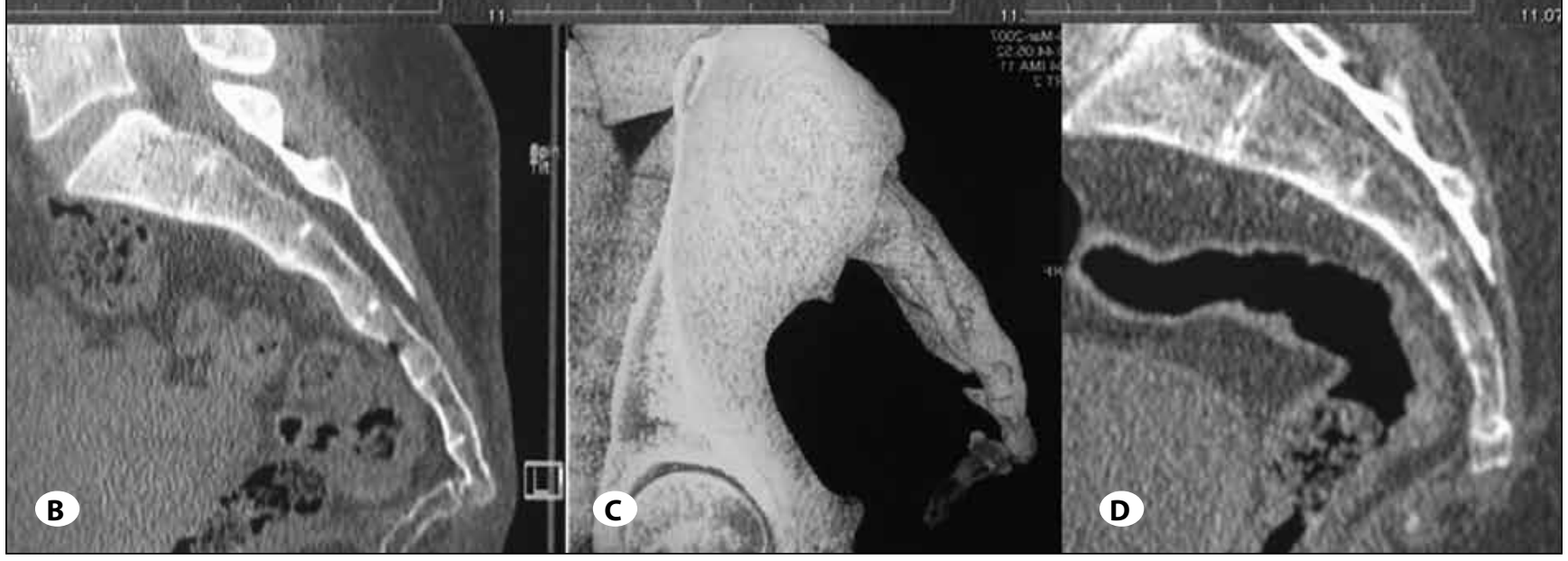

Figure 1: A, B) Preoperative sagittal CT images of a Postacchini Type III case, C) Preoperative 3D CT image. D) Postoperative sagittal CT image of the case. 


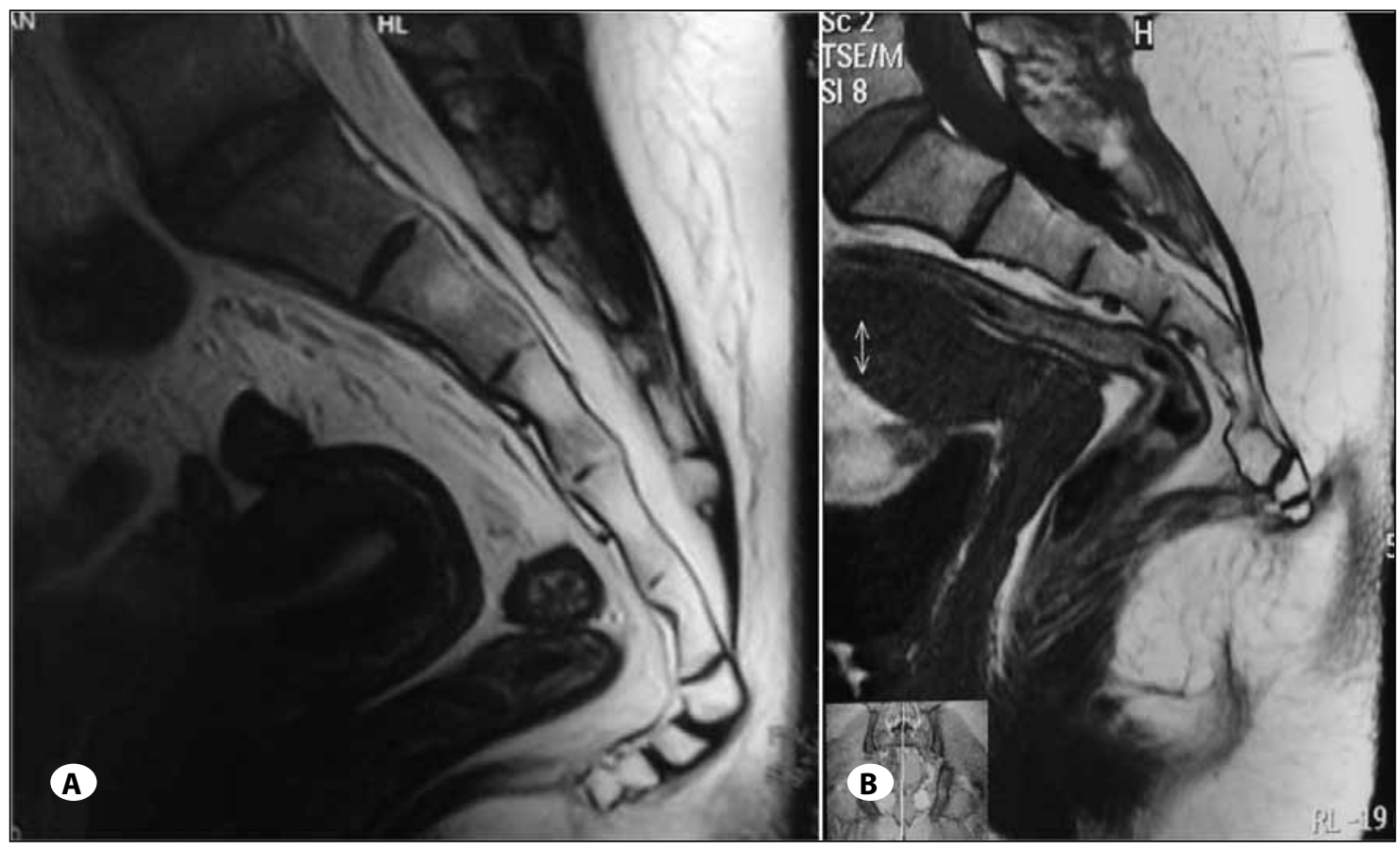

Figure 2:

A) Preoperative sagittal MRI of another Postacchini Type III case,

B) Postoperative sagittal MRI of the case.

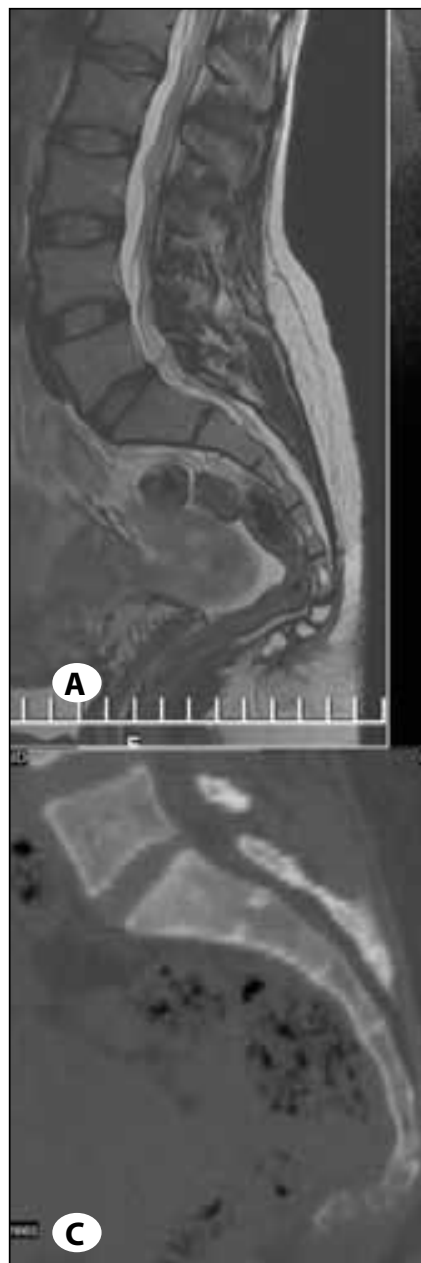

\section{B}

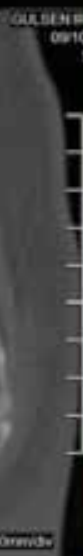

(E)

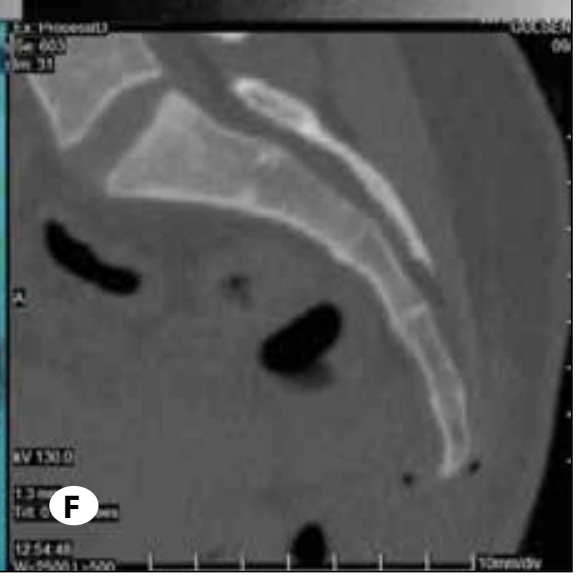

Figure 3:

A) Preoperative sagittal MRI of a Postacchini Type Il case,

B,C) Preoperative sagittal CT images of the same case, D) Incision of the case is less than surgical blade, E) Intraoperative view of the flouroscopy F) Postoperative sagittal CT image of the case. 
Surgical intervention must be considered for patients who do not respond to steroid and local anesthetic injection. Wray reported $91 \%$ success rate for the patients that underwent coccygectomy (11), while Maigne reported $83.3 \%$ success rate for the patients that had coccygectomy (4). Boyne et al. searched for the effect of etiology on coccygectomy results and reported a success rate of $75 \%$ in postpartum and $50 \%$ in idiopathic cases. On the other hand, in their study Trollegaard et al. reported that traumatic coccydynia cases had achieved better results compared to the idiopathic cases (9). In our series, we did not spot the effects of etiology on the outcomes of treatment. However, it may be stated that idiopathic coccygodynia was generally observed to benefit less from both local steroid injection and surgical treatment. (Table II) The pain was more severe especially in traumatic patients with higher angulation due to higher stretching of the Levator ani muscle. It may be stated that this group did not benefit from steroid injection (Table II).

The surgical procedure may require removal of the motor segment or complete removal of the coccyx. Wound infection is the most common post-operative complication of coccygectomy. Coupled with local contamination, the rate of wound infection increases to $22 \%$ (5). Therefore, postoperative prophylactic antibiotic use is recommended (10). In our series, the infection rate was $4 \%$ (one case). One way to prevent infection is to avoid rectal touch during surgery.

Table II: The Patients' Age, Gender and Etiology, Pre-Treatment VAS and Post-Treatment VAS

\begin{tabular}{|c|c|c|c|c|c|c|c|}
\hline Case & Age & Gender & Etiology & Classification & Pretreatment VAS & Posttreatment VAS & Treatment \\
\hline Case 1 & 29 & Female & Pregnancy & Type I & 7 & 2 & Injection \\
\hline Case 2 & 27 & Female & Pregnancy & Type I & 6 & 1 & Injection \\
\hline Case 3 & 37 & Female & Idiopathic & Type I & 6 & 0 & Injection \\
\hline Case 4 & 32 & Female & Pregnancy & Type I & 8 & 1 & Injection \\
\hline Case 5 & 45 & Male & Trauma & Type II & 8 & 1 & Injection \\
\hline Case 6 & 35 & Female & Pregnancy & Type I & 7 & 2 & Injection \\
\hline Case 7 & 34 & Female & Trauma & Type II & 9 & 2 & Injection \\
\hline Case 8 & 32 & Male & Trauma & Type I & 8 & 2 & Surgery \\
\hline Case 9 & 36 & Female & Idiopathic & Type I & 8 & 3 & Surgery \\
\hline Case 10 & 34 & Male & Trauma & Type I & 9 & 1 & Surgery \\
\hline Case 11 & 41 & Female & Idiopathic & Type I & 7 & 2 & Surgery \\
\hline Case 12 & 29 & Male & Trauma & Type IV & 10 & 2 & Surgery \\
\hline Case 13 & 44 & Female & Trauma & Type I & 8 & 1 & Surgery \\
\hline Case 14 & 42 & Female & Trauma & Type I & 8 & 1 & Surgery \\
\hline Case 15 & 36 & Female & Trauma & Type I & 9 & 2 & Surgery \\
\hline Case 16 & 34 & Female & Trauma & Type III & 9 & 2 & Surgery \\
\hline Case 17 & 30 & Female & Idiopathic & Type I & 8 & 2 & Surgery \\
\hline Case 18 & 44 & Female & Trauma & Type I & 9 & 2 & Surgery \\
\hline Case 19 & 38 & Female & Trauma & Type III & 9 & 1 & Surgery \\
\hline Case 20 & 56 & Male & Trauma & Type I & 7 & 0 & Surgery \\
\hline Case 21 & 47 & Female & Trauma & Type I & 7 & 0 & Surgery \\
\hline Case 22 & 36 & Female & Idiopathic & Type I & 8 & 2 & Surgery \\
\hline Case 23 & 34 & Male & Trauma & Type III & 9 & 1 & Surgery \\
\hline Case 24 & 45 & Female & Trauma & Type I & 10 & 2 & Surgery \\
\hline Case 25 & 32 & Female & Trauma & Type I & 9 & 2 & Surgery \\
\hline Case 26 & 55 & Female & Trauma & Type I & 8 & 1 & Surgery \\
\hline Case 27 & 33 & Male & Trauma & Type I & 8 & 0 & Surgery \\
\hline Case 28 & 32 & Female & Trauma & Type I & 9 & 2 & Surgery \\
\hline Case 29 & 30 & Female & Idiopathic & Type I & 8 & 2 & Surgery \\
\hline Case 30 & 51 & Male & Trauma & Type I & 7 & 0 & Surgery \\
\hline Case 31 & 29 & Female & Trauma & Type I & 9 & 2 & Surgery \\
\hline Case 32 & 34 & Female & Trauma & Type I & 8 & 1 & Surgery \\
\hline
\end{tabular}




\section{CONCLUSION}

Coccygodynia is underrated in neurosurgical practice. Basic approaches in the treatment of coccygodynia include manoeuvres such as rectal massage in addition to several conservative treatment procedures, local injections and surgical treatment. While local steroid injection is an effective method of treatment for Type I patients, coccyx removal is an effective method for controlling the pain in patients with trauma history and in Type II, III and IV patients.

\section{REFERENCES}

1. Ballain B, Eisenstein M, Alo G, Darby A, Cassar-Pullicino V, Roberts S, Jaffray D: Coccygectomy for coccydynia: Case series and review of literature. Spine 31:E414-420, 2006

2. Blocker O, Hill S, Woodacre T: Persistent coccydynia - the importance of a differential diagnosis. BMJ Case Rep 2011:2011, pii: bcr0620114408

3. Fogel G, Cunningham P, Esses S: Coccygodynia: Evaluation and management. J Am Acad Orthop Surg 12:49-54, 2004

4. Maigne JY, Guedj S, Straus C: Idiopathic coccygodynia. Lateral roentgenograms in the sitting position and coccygeal discography. Spine 19:930-934, 1994
5. Maigne J, Doursounian L, Chattelier G: Causes and mechanisms of common coccydynia: Role of body mass index and coccygeal trauma. Spine 25:3072-3079, 2000

6. Porter KM, Khan MAA, Piggott H: Coccydynia: Retrospective review. J Bone Joint Surg 63-B: 635-636, 1981

7. Postacchini F, Massobrio M: Idiopathic coccygodynia. Analysis of fifty-one operative cases and a radiographic study of the normal coccyx. J Bone Joint Surg (Am) 65:1116-1124, 1983

8. Rao G, Chang GJ, Suk I, Gokaslan Z, Rhines LD: Midsacral amputation for en bloc resection of chordoma. Neurosurgery $66: 41-44,2010$

9. Trollegaard AM, Aarby NS, Hellberg S: Coccygectomy: An effective treatment option for chronic coccydynia: Retrospective results in 41 consecutive patients. J Bone Joint Surg 92: 242-245, 2010

10. Wood KB, Mehbod AA: Operative treatment for coccygodynia. J Spinal Disord Tech 17:511-515, 2004

11. Wray CC, Easom S, Hoskinson J: Coccydynia. Aetiology and treatment. J Bone Joint Surg Br 73(2):335-338, 1991 